\title{
Pengaruh Limbah Buah Nanas (Ananas comosus L.Merr) Terfermentasi dalam Pakan terhadap Produktivitas Broiler
}

\section{The Effect Fermentated Pineapple (Ananas comosus L.Merr) Waste in Feed on Broiler Productivity}

\author{
M. Syahayani ${ }^{1}$, I. Panjaitan ${ }^{1 *}$, D. D. Putri ${ }^{1}$ \\ ${ }^{1}$ Jurusan Peternakan Politeknik Negeri Lampung, \\ Jln. Soekarno Hatta No 10 Rajabasa Bandar Lampung, 35144 \\ *E-mail korespondensi: imelpolinela27@polinela.ac.id
}

\begin{abstract}
The availability of commercial feed raw materials is a limiting factor that causes the price of commercial feed for broilers to be expensive. Therefore it is necessary to use additional feed or alternative feed with good nutritional content, available throughout the year at a relatively affordable and acessible. Pineapple waste is an alternative feed that is cheap, easy to obtain and available all year round. The weakness of pineapple waste is that the crude fiber content is quite high, but with fermentation technology this problem can be overcome. The research analyze the effect of fermented pineapple (Ananas comosus L.Merr) waste in feed on broiler productivity. The research was conducted from November to December 2019 at the Lampung State Polytechnic cattle stable. The experiment was designed with two treatments. The first treatment $(P O=$ control $)$ of commercial feed without TLBNF. Second treatment (P1) Commercial Feed 92\% + 8\% TLBNF. The treated feed was given at the beginning of the third week to the end of the fourth week. The data for each variable was tested by means of the T-test. Based on the results and discussion, it can be concluded that: The use of $8 \%$ fermented pineapple waste flour (TLBNF) in commercial feed does not affect feed consumption, body weight gain, feed conversion.
\end{abstract}

Keywords: broiler, pineapple waste, productivity

Diterima: 2 Agustus 2020, disetujui 10 Desember 2020

\section{PENDAHULUAN}

Pakan merupakan faktor yang sangat penting dalam menentukan keberhasilan usaha pada peternakan unggas. Ketersediaan bahan baku pakan komersial merupakan faktor pembatas yang menyebabkan harga pakan komersial unggas menjadi mahal. Pengggunaan pakan tambahan atau pakan alternatif diperlukan untuk menekan harga. Pakan tambahan yang tersedia sepanjang tahun dengan harga relatif murah dan mudah bisa dijadikan sebagai penekan harga untuk mengurangi biaya pakan.

Limbah buah nanas merupakan salah satu pakan alternatif yang murah, mudah didapat dan tersedia sepanjang tahun (Ibrahim et al., 2016). Limbah buah nanas terdiri dari kulit, mahkota buah dan tonggol dapat mencapai $27 \%$ dari total produksi buah nanas (Kusuma et al., 2019). Kandungan nutrisi buah nanas 8,86\% protein kasar, 19,49 \% serat kasar, 1,88 \% lemak kasar, 4,52 \% abu dan 65,68 \% BETN (Noviandi dan Yaman, 2018). Buah nanas juga mengandung enzim bromelin (bromelain) yang merupakan $95 \%$ protease sistein yang dapat memecah protein (Arti et al., 2018). Kulit nanas masih memiliki nilai gizi yang baik yaitu bahan kering 


\section{Syahayani, dkk.: Pengaruh Limbah Buah Nanas (Ananas comosus L.Merr) Terfermentasi dalam Pakan terhadap Produktivitas Broiler/Peterpan 2 (2): 36-41}

(BK) 88,95 \%, abu 3,82 \%, serat kasar (SK) 27,09 \%, protein kasar (PK) 8,78 \%, dan lemak kasar (LK) $1,15 \%$ (Nurhayati et al., 2014).

Kendala pemanfaatan limbah buah nanas untuk unggas yaitu serat kasar yang cukup tinggi. Serat kasar yang tinggi mengakibatkan zat makanan sulit dicerna oleh ternak unggas sehingga dapat menurunkan kecernaan zat-zat makanan. Fermentasi dapat membantu mengurai serat kasar sehingga lebih mudah dicerna. Fermentasi merupakan suatu proses memanfaatkan mikroba untuk memperbaiki kualitas suatu bahan serta relatif murah dan mudah dilakukan. Mikroba yang umum digunakan dalam fermentasi bahan dengan serat kasar tinggi adalah Trichoderma viride. Kapang Trichoderma viride mampu secara spesifik menghasilkan enzim selulase yang potensial untuk mendegradasi bahan lignoselulotik menjadi glukosa dan meningkatkan kandungan protein di dalam biomassa. Pemanfaatan Trichoderma viride dalam proses fermentasi diketahui dapat meningkatkan kandungan nutrisi (Setiyatwan, 2007).

Fermentasi berhubungan dengan kerja enzim yang diproduksi oleh mikroorganisme. Enzim-enzim yang dihasilkan dari golongan kapang diproduksi melalui proses fermentasi media padat (Setiyatwan, 2007). Trichoderma viride diketahui sebagai sumber enzim selulase komersial dan dapat menginduksi enzim yang berbeda sesuai dengan substrat yang digunakan (Melati et al., 2012). Enzim lain yang dapat dihasilkan oleh Trichoderma viridae antara lain protease, lipase, dan pektinase (Rogers, 2002). Proses fermentasi dapat meningkatkan enzim protease. Dimana enzim protease berfungsi untuk memecahkan protein dalam makanan menjadi asam amino. Penggunaan tepung limbah buah nanas fermentasi dalam pakan diharapkan dapat meningkatkan produktivitas broiler. Karena didalam tepung limbah buah nanas terdapat enzim selulase, dimana Eenzim selulase dapat mengurai sel dinding selulosa tanaman yang dimakan oleh hewan herbivora.

\section{METODE PENELITIAN}

Persiapan bahan pakan untuk penelitian dilaksanakan 2 minggu sebelum penelitian dimulai. Uji biologis pakan tepung limbah buah nanas fermentasi (TLBNF) dalam pakan komersial pada broiler dilaksanakan pada kandang panggung, Politeknik Negeri Lampung.

Bahan yang digunakan untuk menunjang penelitian ini antara lain limbah buah nanas fermentasi, pakan komersil (BR1 dan BR2), Trichoderma viride, vaksin, vitachick, air minum dan DOC. Limbah buah nanas diperoleh dari pasar tempel Sukarame, Bandar Lampung. Peralatan yang digunakan yaitu silo, timbangan, golok, nampan, grinding, mixer, baskom, terpal, karung, tali, spuit, satu paket alat klining dan kandang.

Penelitian ini dilaksanakan dengan pakan berbeda, pakan komesial (P0) dan pakan komersial dan limbah buah nana fermentasi sebanyak 8\% (P1) sesuai dengan penelitian sebelumnya menurut (Muharlien et al., 2011), dengan komposisi seperti terlihat pada Tabel 1.

Tabel.1 Komposisi pakan perlakuan

\begin{tabular}{|c|c|c|}
\hline Perlakuan & Pakan Komersil & LBNF \\
\hline P0 & $100 \%$ & 0 \\
\hline P1 & $92 \%$ & $8 \%$ \\
\hline
\end{tabular}

Pakan perlakuan diberikan pada awal minggu ke-3 sampai dengan panen, dengan pemberian adlibitum. Kandungan nutrisi pakan komersil, limbah buah nanas fermentasi dan pakan perlakuan disajikan pada Tabel 2 . 
Tabel 2 Kandungan nutrisi pakan komersial BRII(P0) dan limbah buah nanas fermentasi (LBNF) pakan perlakuan (P1).

\begin{tabular}{llllll}
\hline & BRII & LBNF & P0 & P1 & $\begin{array}{l}\text { Kebutuhan fase } \\
\text { finisher }\end{array}$ \\
\hline EM & 3.200 & $1.995 * *$ & 3.200 & $3.103,6$ & $3.080-3190$ \\
PK & 19 & $7,44 * * *$ & 19 & 18,08 & $19-20$ \\
LK & 5 & $1,23 * * *$ & 5 & 4,69 & 5 \\
SK & 5 & $17,47 * * *$ & 5 & 6 & 5 \\
Ca & 0,9 & $0,52 * *$ & 0,9 & 0,84 & 0,9 \\
P & 0,9 & $0,24 * *$ & 0,9 & 0,81 & 0,9 \\
\hline
\end{tabular}

Keterangan :

* Japfa Comfeed.

** Mahata dkk (2016)

*** Uji proksimat Laboratorium THP (2020)

**** Kusuma. $\operatorname{dkk}(2019)$.

Metode yang digunakan dalam penelitian ini adalah metode percobaan, yaitu dengan membandingkan penampilan produktivitas broiler yang dipelihara dengan pakan berbeda. Data yang dikoleksi terkait produktivitas diuji dengan T-test.

Limbah buah nanas diambil dari pasar tempel, Sukarame, Bandar Lampung. Pengumpulan dilakukan selama 6 hari dengan jumlah limbah buah nanas $60 \mathrm{~kg}$. Setelah itu dilakukan pemotongan LBN dengan potongan-potongan kecil,tahapan selanjutnya dilakukan fermentasi dengan menggunakan kapang trichoderma viridae. Kapang trichoderma viridae digunakan sebanyak $7 \%$ dari berat limbah kulit nanas yang akan difermentasi (Brata, 2008). Fermentasi dilakukan selama 8 hari. Setelah proses fermentasi dilakukan penjemuran limbah buah nanas fermentasi dibawah sinar matahari selama 3--4 hari atau mencapai kadar air $12--14 \%$. Selanjutnya LBNF digiling hingga menjadi tepung. $60 \mathrm{~kg}$ limbah buah nanas dapat menghasilkan $15 \mathrm{Kg}$ TLBNF. Terjadi penyusutan sebanyak 75\%. Untuk kebutuhan tepung limbah buah nanas fermentasi selama perlakuan 14 hari membutuhkan sebanyak $8 \%$ dari jumlah pemberian. Diagram alir pembuatan TLBNF disajikan pada Gambar1.

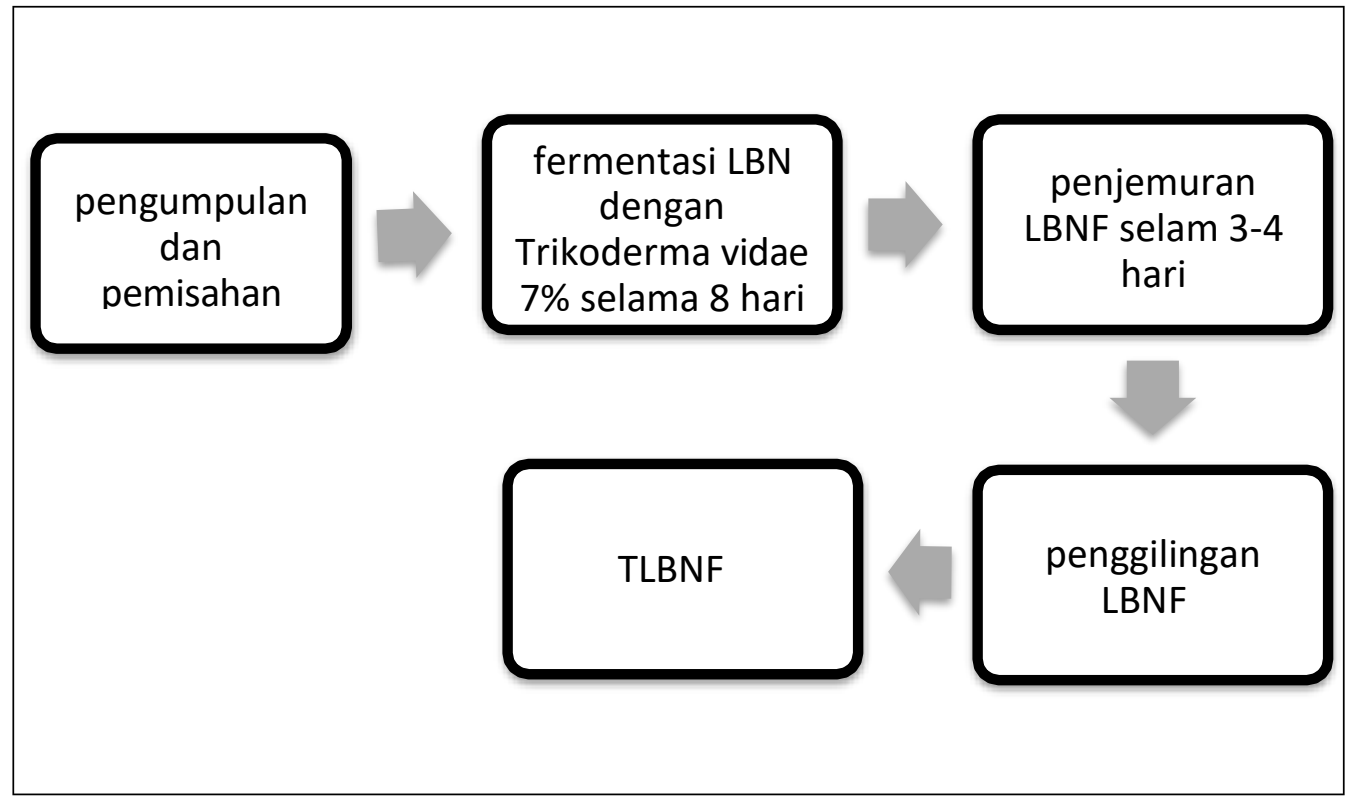

Gambar 1. Diagram alir pembuatan TLBNF 


\section{Syahayani, dkk.: Pengaruh Limbah Buah Nanas (Ananas comosus L.Merr) Terfermentasi dalam Pakan terhadap Produktivitas Broiler/Peterpan 2 (2): 36-41}

Semua alat bekas pemeliharaan sebelumnya dikeluarkan dan dicuci sampai bersih dengan diterjen. Setelah pembersihan peralatan selanjutnya lakukan pembersihan kandang. Kandang disikat dan dibilas dengan air, setelah bersih dilakukan pengapuran agar virus atau bakteri tidak ada yang tertinggal didalam kandang. Setelah semua bersih lakukan persiapan chick in.

1. Chick in, Pada saat chick in ayam diberi air gula agar tidak stres

2. Pemberian pakan dan air minum. Pakan yang diberikan 2 minggu pertama pakan komersil, sedangkan untuk minggu ke 3--4 pemberian pakan sesuai pakan perlakuan yang dirancang.

3. Setiap periode dilakukan perhitungan konsumsi dan pertambahan bobot badan.

4. Panen ayam pada umur 28 hari

5. Ayam yang digunakan kontrol 50 ekor dan perlakuan 50 ekor dengan menggunakan uji T-test tidak berpasangan.

Parameter yang diamati:

1. Konsumsi Pakan

Konsumsi Pakan (gr) = Jumlah pakan yang diberikan - sisa pakan

2. Pertambahan Bobot Badan

PBB $($ gr/ekor $)=$ BB Akhir Pengamatan - BB Awal Pengamatan

3. Konversi Pakan

$$
\text { konversi pakan }=\frac{\text { konsumsi pakan }}{\text { pertambahan berat badan }}
$$

\section{HASIL DAN PEMBAHASAN}

Hasil penelitian pengaruh penggunaan $8 \%$ tepung limbah buah nanas fermentasi (TLBNF) dalam pakan komersil disajikan pada Tabel 3.

Tabel 3. Rataan konsumsi, bobot badan, pertambahan bobot badan serta konversi pakan broiler pengaruh penggunaan $8 \%$ TLBNF dalam Pakan pada fase finisher.

\begin{tabular}{lll}
\hline Parameter & $\mathrm{P} 0$ & $\mathrm{P} 1$ \\
\hline Konsumsi (g/ekor/hari) & $98,08 \pm 2,49^{\mathrm{tn}}$ & $97,51 \pm 2,72^{\text {tn }}$ \\
Bobot Badan Awal (g/ekor) & $519,04 \pm 37,17^{\text {tn }}$ & $513,89 \pm 27,26^{\text {tn }}$ \\
Bobot Badan Akhir (g/ekor) & $1440,55 \pm 88,44^{\text {tn }}$ & $1410,26 \pm 73,06^{\text {tn }}$ \\
Pertambahan Bobot Badan (g/ekor) & $921,51 \pm 95,72^{\text {tn }}$ & $896,36 \pm 81,05^{\text {tn }}$ \\
Konversi & $1,51 \pm 0,16^{\text {tn }}$ & $1,53 \pm 0,14^{\text {tn }}$ \\
\hline
\end{tabular}

Keterangan: P0 : Ransum Basal P1 : Ransum Basal + 8\% TLNBF

TLNBF : Tepung Limbah buah nanas fermentasi

\section{Konsumsi Pakan}

Konsumsi pakan merupakan jumlah pakan yang dimakan dalam waktu tertentu yang akan digunakan oleh ternak untuk memenuhi kebutuhan hidup dan produksi. Menurut Bell and Weaver (2002), konsumsi pakan tiap ekor ternak berbeda, hal ini dipengaruhi oleh bobot badan, tingkat produksi, tingkat cekaman, aktivitas ternak, kandungan energi dalam pakan dan suhu lingkungan. Rataan konsumsi broiler selama 14 hari pada fase finisher yang diberi pakan komersial 98,08 $\pm 2,49 \mathrm{~g} /$ ekor/hari dan broiler yang diberi $8 \%$ TLBNF dalam pakan 97,51 $\pm 2,72 \mathrm{~g} /$ ekor/hari. Hasil uji T-test memperlihatkan bahwa penggunaan $8 \%$ TLBNF dalam pakan tidak memberikan pengaruh yang nyata $(\mathrm{P}<0,05)$ terhadap konsumsi pakan fase finisher, dapat dilihat pada Tabel 3 . Sehingga dapat dikatakan bahwa penggunaan $8 \%$ TLBNF dalam pakan broiler fase finisher memberikan efek yang sama dengan pakan komersial terhadap konsumsi pakan. Hal ini disebabkan karena kandungan zat makanan dalam pakan relative sama (Tabel 2). Salah satu faktor yang mempengaruhi konsumsi pakan adalah 
kandungan zat-zat makanan dalam pakan (Rasyaf, 2007). Ayam mengkonsumsi pakan untuk memenuhi kebutuhan energi dan ayam akan menghentikan konsumsi pakan apabila kebutuhan energi telah terpenuhi (Suprijatna et al., 2005).

\section{Pertambahan Bobot Badan}

Pertambahan bobot badan merupakan salah satu kriteria yang digunakan untuk mengukur pertumbuhan. Pemberian pakan komersial (P0) cenderung meningkatkan pertambahan bobot badan lebih tinggi (921,51 $\pm 95,72$ g/ekor) dibandingkan perlakuan 8\% TLBNF dalam pakan (896,36 $\pm 81,05$ g/ekor), namun pertambahan bobot badan broiler dengan aplikasi $8 \%$ TLBNF terlihat lebih seragam. Tingginya pertambahan bobot badan pada ayam broiler yang diberikan pakan komersial dikarenakan bahwa kandungan dan komposisi nutrisi pakan komersial sudah memenuhi standar kebutuhan broiler. Hasil uji $\mathrm{T}$ menunjukkan bahwa pemberian $8 \%$ TLBNF dalam pakan tidak menunjukkan perbedaan yang nyata $(\mathrm{P}<0,05)$ terhadap pertambahan bobot badan broiler fase finisher. Diduga pakan perlakuan dengan $8 \%$ TLBNF dari sisi komposisi zat makanan sudah mendekati kebutuhan ayam broiler fase finisher. Perbedaan yang tidak signifikan juga disebabkan tingkat konsumsi yang tidak berbeda nyata $(\mathrm{P}<0,05)$.

Konsumsi pakan memiliki korelasi positif dengan pertambahan bobot badan. Fadilah, (2005) menambahkan bahwa faktor yang mempengaruhi besar kecilnya pertambahan bobot badan broiler adalah konsumsi pakan dan terpenuhinya kebutuhan zat makanan ayam pedaging. Rasyaf, (2011), menyatakan bahwa konsumsi pakan berkaitan dengan masuknya unsur nutrien ke dalam tubuh ayam. Semakin tinggi pakan yang terkonsumsi maka pertambahan bobot badan yang dihasilkan akan semakin meningkat atau sebaliknya. Hal ini sesuai dengan pendapat Abidin, (2003) menyatakan bahwa faktor pertumbuhan berat badan adalah konsumsi pakan. Pendapat ini juga didukung oleh Ichwan, (2003) yang menyatakan bahwa secara umum penambahan bobot badan akan dipengaruhi oleh jumlah konsumsi pakan yang dimakan dan kandungan nutrisi yang terdapat didalam pakan tersebut.

\section{Konversi Pakan}

Konversi pakan digunakan untuk melihat efisiensi penggunaan pakan oleh ternak atau dapat dikatakan efisiensi pengubahan pakan menjadi produk akhir yakni pembentukan daging. Secara numerik nilai konversi

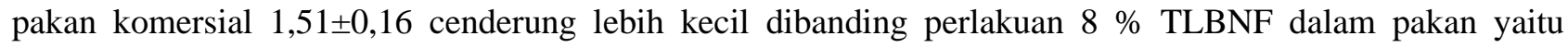
$1,53 \pm 0,14$. Namun uji T menunjukkan tidak ada perbedaan yang nyata $(\mathrm{P}<0,05)$ terhadap nilai konversi pakan. Hal ini berarti pemberian TLBNF sampai taraf $8 \%$ dari total pakan tidak mempengaruhi nilai konversi pakan ayam broiler. Konversi pakan merupakan perbandingan antara jumlah konsumsi pakan dan pertambahan bobot badan pada satuan yang sama. Hal ini sesuai dengan pendapat Basuki, 2002) yang menyatakan bahawa faktor yang mempengaruhi konversi pakan adalah konsumsi pakan dan pertambahan bobot badan.

\section{KESIMPULAN DAN SARAN}

\section{Kesimpulan}

Berdasarkandari hasil dan pembahasan, dapat disimpulkan bahwa: Penggunaan $8 \%$ tepung limbah buah nanas fermentasi dalam pakan komersial tidak mempengaruhi konsumsi pakan, pertambahan bobot badan, konversi pakan dan mortalitas broiler. Selama dua minggu pemeliharaan Konsumsi pakan 97,51g, pertambahan bobot badan 896,36 g dengan konversi 1,53.

\section{Saran}

Perlu penelitian lebih lanjut penggunaan tepung limbah buah nanas fermentasi (TLBNF) dengan menggunakan kapang jenis lain. 
Syahayani, dkk.: Pengaruh Limbah Buah Nanas (Ananas comosus L.Merr) Terfermentasi dalam Pakan terhadap Produktivitas Broiler/Peterpan 2 (2): 36-41

\section{DAFTAR PUSTAKA}

Abidin, Z. 2003. Meningkatkan Produktivitas Ayam Ras Pedaging. Jakarta. Agromedia Pustaka.

Arti, I. M, Huda A. N, Pratama E. Y. 2019. Karakteristik Fisik Daging Sapi Has Dalam Pada Perendaman Berbagai Bagian Buah Nanas. FoodTech: Jurnal Teknologi Pangan. 2(2):11-23.

Basuki, P. 2002. Pengantar Ilmu Ternak Potong dan Kerja. Yogyakarta. Universitas Gadjah Mada. Yogyakarta.

Bell, D. dan W. D. Weaver, Jr. 2002. Commercial Chicken Meat and Egg Production, 5 edition. New York. Springer Science and Busines Media Inc.New York.

Brata. B. 2008. Uji lama fermentasi dan persentase inokulum melalui kapang Trichoderma Harzianum terhadap peningkatan kualitas isi rumen sebagai pakan ayam. Jurnal Sain Peternakan Indonesia. 3(2): $63-68$.

Fadilah. 2005. Panduan Mengelola Peternakan Ayam Broiler Komersial. Jakarta: Agromedia Pustaka.

Ibrahim, W. Mutia., R. dan Nurhayati. 2016. Penggunaan kulit nanas fermentasi dalam ransum yang mengandung gulma berkhasiat obat terhadap konsumsi nutrient ayam broiler. Jurnal Agripet. 16(2):76-82.

Ichwan. 2003. Membuat Pakan Ayam Ras Pedaging. Jakarta: Agromedia Pustaka Utama.

Kusuma, A., Chuzaemi, S., dan Mashudi, M. .2019. Pengaruh lama waktu fermentasi limbah buah nanas (Ananas comosus L. Merr) terhadap kualitas fisik dan kandungan nutrien menggunakan Aspergillus niger. Jurnal Nutrisi Ternak Tropis. 2(1): 1-9.

Mahata, M. E., Y. Heryandi dan Adrizal. 2016. Fermentasi limbah nenas (Ananas comosus (L.) Merr) dengan mikroorganisme lokal (MOL) untuk pakan unggas. Laporan Penelitian Hibah Riset Guru Besar. Padang. Universitas Andalas Tahun Pertama.

Melati, I. Mulyasari. Azwar. Z. I. 2012. Pengaruh fermentasi menggunakan Tricoderma Viride dan Phanerochaete chrysosporium serta gabungan keduanya terhadap komposisi nutrien tepung jagung sebagai bahan baku pakan ikan. Jurnal Riset Akuakultur. 7(1) : 41- 47.

Muharlien, Citra. Natsir. Z.H. 2011. Efek penambahan tepung kulit nanas(Ananas comucus (L) Merr.) dalam pakan terhadap jumlah telur dan kualitas telur itik. Jurnal Ilmu Dan Teknologi Hasil Ternak. 6(2): 1520.

Nurhayati, Nelwida, Berliana. 2014. Pemanfatan kombinasi gulma berkhasiat obat sebagai bahan pakan aditif dalam pakan ayam broiler yang mengandung kulit nanas yang difermentasi dengan yoghurt. Jurnal Agripet.16(1): 31-36.

Noviandi, I, Yaman M. A. Nurliana R, Razali. 2018. Pengaruh pemberian kulit nanas (Ananas comosus L. Merr) fermentasi terhadap persentase karkas dan kolesterol ayam potong. Jurnal Agripet. 18(2): 123128.

Rasyaf, M. 2007. Beternak Itik Komersil. Kanisius. Yogyakarta. . 2011. Panduan Beternak Ayam Pedaging. Penerbit Swadaya. Jakarta.

Rogers, J. M. 2002. Diamond V xp TM DFM sets the standard in microbial feed technology. http:// www. Diamond. Com/ newsrelease/ xp_dfm_aug 2000. htmL

Setiyatwan, H., 2007. Peningkatan kualitas nutrisi duckweed melalui fermentasi menggunakan Trichoderma harzianum. Jurnal Ilmu Ternak Universitas Padjadjaran. 7(2): 113-116.

Suprijatna, E. U. Atmomarsono. Kartasujana. R. 2005. Ilmu Dasar Ternak Unggas. Penerbit Penebar Swadaya. Jakarta. 